\title{
Raw Secondary Metabolites of Trichoderma harzianum T10 in Tapioca Flour Towards Cucumber Damping-off
}

\author{
Loekas Soesanto*, Hidayatul Ilahiyyah, Endang Mugiastuti, Abdul Manan, Rostaman \\ Faculty of Agriculture, Universitas Jenderal Soedirman, Indonesia \\ *Email: lukassusanto26@gmail.com
}

Submitted: 23 May 2020. Revised: 16 June 2020. Accepted: 1 July 2020

\begin{abstract}
Trichoderma harzianum is effective for controlling soil-borne pathogenic fungi and producing secondary metabolites. When applied in the field, the raw secondary metabolites are quickly decreased directly by sunlight. This research aimed to obtain the most effective concentration of tapioca flour in development of raw secondary metabolites of Trichoderma harzianum T10, its effect on damping-off and growth of cucumber. This research was carried out at the screen house and the Plant Protection Laboratory, Faculty of Agriculture, Jenderal Soedirman University. The study was conducted in two stages, i.e., in vitro and in planta. The in vitro stage used completely randomized design with five repetitions and five treatments consisted of T. harzianum T10 in Potato Dextrose Broth, and in $0.5 ; 1 ; 1.5$; and $2 \%$ of tapioca flour media. In in planta, randomized block design was used with five repetitions and six treatments consisted of control, T. harzianum T10 in PDB, and in $0.5 ; 1 ; 1.5$, and $2 \%$ of tapioca flour media. Variables observed were density of conidia, disease incubation period, disease incidence, AUDPC, maximum growth potential, germination ability, plant height, canopy fresh weight, root length, and fresh root weight. Result of the research showed that the highest conidial density $\left(1.23 \times 10^{7} \mathrm{conidia} \mathrm{mL}^{-1}\right)$ of T. harzianum T10 was found in 2\% tapioca flour with an increase of $63.28 \%$ compared to the PDB. The tapioca flour of 1 and $2 \%$, and PDB could suppress the disease incidence by $81.82 \%$. The lowest AUDPC was at $2 \%$ tapioca flour. The raw secondary metabolites could not delay the incubation period significantly and increase cucumber plant growth. Tapioca flour with the right concentration to produce high conidia density and high raw secondary metabolites. The benefits are to find other cheaper ingredients in promoting antagonistic fungal growth and the use of antagonistic fungal bioactive compounds to control plant pathogen
\end{abstract}

Key words: Cucumber; Damping-Off, Raw Secondary Metabolites; Tapioca Flour; Trichoderma harzianum T10

How to Cite: Soesanto, L., Ilahiyyah, H., Mugiastuti, E., Manan, A., \& Rostaman, R. (2020). Raw Secondary Metabolites of Trichoderma harzianum T10 in Tapioca Flour Towards Cucumber Damping-off. Biosaintifika: Journal of Biology \& Biology Education, 12 (2), 226-234

DOI: http://dx.doi.org/10.15294/biosaintifika.v12i2.24567

\section{INTRODUCTION}

Trichoderma sp. is considered as potential antagonistic fungus that is often used for biological control (Munir et al., 2013; Ghazanfar et al., 2018). Trichoderma sp. works against fungal phytopathogens either indirectly by competing for nutrients and space, modifying environmental conditions, promoting plant growth and plant defensive and antibiosis mechanisms; or directly through mechanisms such as mycoparasitism. One spesies of Trichoderma spp. is $T$. harzianum Rifai (Chaverri et al, 2015). T. harzianum has been isolated from various plant rhizospheres and tested for its effect on several diseases. For example, T. harzianum T10 isolated from ginger rhizosphere against Fusarium wilt (Soesanto et al., 2013) and Phytophthora wilt (Soesanto et al., 2019). Trichodema sp. has the ability as a mycoparasite (Bouziane et al., 2016) and antibiotics (Vinale et al., 2014), as well as producing extracellular compounds that can be toxic to pathogens (Al-Taweil et al., 2009) and enzymes that can degrade pathogen cell walls (Bae et al., 2017).
T. harzianum is effective for controlling soil-borne pathogenic fungi (Munir et al., 2013; Ghazanfar et al., 2018). One of the soil-borne fungi is Pythium spp. which with their wide distribution and host range causing damping-off to cucumber (Rostami et al., 2015; Lamichhane et al., 2017). Efforts to control damping-off that have been carried out, including using soluble silicon (Si) (Fayadh \& Aledani, 2011; Yassin et al., 2016), cultivars resistance (Rostami et al., 2015), and biological control (Soekarno et al., 2014; Aljarah, 2017). Synthetic chemical pesticides have been used as well, but this approach is likely to be limited due to negative impacts on human health and the environment (Keswani et al., 2019). The secondary metabolites produced by agriculturally important microorganisms have an important role in improving the quality of the crops. T. harzianum as a biological control agent can produce secondary metabolites (Mukherjee et al., 2012; Vinale et al., 2012; 2014).

Microbes, included biological agents, when applied in the field are quickly decreased in population directly by sunlight (Rashid et al., 2016) and by chemical substances (Li et al., 2017; Muturi et al., 
2017) so as to limit their ability. One strategy to avoid the degradation is the use of raw secondary metabolites in liquid formula (Pathma et al., 2011; Mutawila et al., 2015). Several studies have utilized carriers for liquid formulation of Trichoderma sp. biofungicides, such as talc (Sriram et al., 2011; Mukherjee et al., 2013; Patel and Patel, 2014), compost (Panahian et al., 2012; Damiri et al., 2014), and molasses (Rahnama, 2012). However, the use of tapioca flour for liquid formulations is still limited for biological control.

This study aimed to determine the most effective concentration of tapioca flour in development of raw secondary metabolites of $T$. harzianum $\mathrm{T} 10$, the effect of $T$. harzianum $\mathrm{T} 10$ in the formula on damping off and on growth of cucumbers. The benefits are to find other cheaper ingredients in promoting antagonistic fungal growth and the use of antagonistic fungal bioactive compounds to control plant pathogen

\section{METHODS}

\section{Preparation of Pythium spp.}

Pythium spp. were isolated from damping-off symptomatic chilli seedlings at Sikapat Gandatapa Village, Sumbang District, Banyumas Regency. The infected seedling was cut $1-2 \mathrm{~cm}$, then aseptically grown on the PDA (potato dextrose agar) for identifi- cation (Patil \& Rathore, 2018). The culture was purified and maintained for further studies.

\section{Preparation of $T$. harzianum T10}

T. harzianum T10 grown on PDA was propagated on cracked corn media by taking isolates using cork drill $\pm 5 \mathrm{~mm}$ in diameter. Inoculated cracked corn media with $T$. harzianum T10 was incubated for 6-14 days until the spores and mycelium grew evenly (Heydari \& Pessarakli, 2010; Gusnawaty et al., 2014).

\section{Preparation of raw secondary metabolites}

Raw secondary metabolites of T. harzianum T10 were made in potato dextrose broth (PDB) with tapioca flour as the carrier. The liquid media of tapioca flour $\left(5,10,15\right.$, and $\left.20 \mathrm{~g} \mathrm{~L}^{-1}\right)$ was made by mixing the flour with sugar $10 \mathrm{~g} \mathrm{~L}^{-1}$ and heated to boiling. Each medium was filled into a sterile glass bottle for 100 $\mathrm{mL}$, cooled, and added with $T$. harzianum $\mathrm{T} 10$ from the cracked corn media with a density of $10^{6}$ conidia $\mathrm{mL}^{-1}$. Furthermore, each treatment was shaken using a shaker with a speed of $150 \mathrm{rpm}$ for 7 days at room temperature (Han et al., 2012). The mixture was centrifuged at $13000 \mathrm{rpm}$ for $5 \mathrm{~min}$. at room temperature. The supernatant was then transferred into sterile bottle (Figure 1) (Wu et al., 2017).

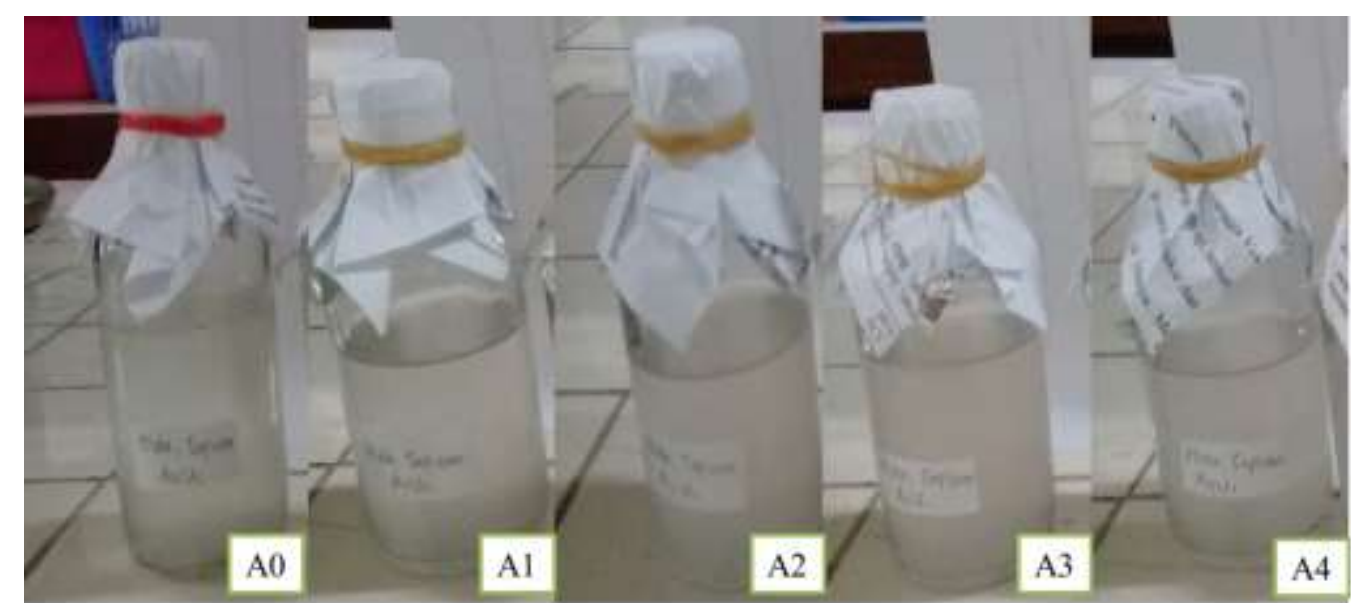

Figure 1. Raw secondary metabolites of $T$. harzianum $\mathrm{T} 10$ in different media. Note: $\mathrm{A} 0=\mathrm{PDB}, \mathrm{A} 1-\mathrm{A} 4=$ tapioca flour at concentration of $0.5 ; 1 ; 1.5$; and $2 \%$, respectively.

\section{Application of raw secondary metabolites}

In the planting hole, two cork drill Pythium spp. were placed. The planting media were composed by soils mixed with cow manure $(1: 1, \mathrm{w} / \mathrm{w})$. Cucumber seeds were then placed on top and covered with thin layer of soils. The raw secondary metabolites of $T$. harzianum $\mathrm{T} 10$ according to the treatment were dripped on the seeds as much as $50 \mathrm{~mL}$. As a control, Pythium spp. was inserted into the hole, covered with soil, then cucumber seeds were placed on it and covered with soil again. The experiment was carried out in the screen house.

\section{In vitro experiment}

In vitro experiments were arranged in a completely randomized design consisting of five replications and five treatments $(\mathrm{A} 0=$ raw secondary metabolites made in PDB, and A1-A4 = in tapioca flour of 5, 10, 15 , and $20 \mathrm{~g} \mathrm{~L}^{-1}$, respectively).

\section{In planta experiment}

In planta experiments were arranged in a randomized block design with five replications and six treatments (control, T. harzianum T10 secondary metabo- 
lites in PDB, and in tapioca flour with concentrations of $5,10,15$, and $20 \mathrm{~g} \mathrm{~L}^{-1}$ ).

\section{Observed variables}

The conidial density was calculated by preparing a conidial suspension and by using a haemocytometer. The conidial suspension was taken as much as $1 \mathrm{~mL}$ using the eyedropper while stirring. The suspension onto the haemocytometer was covered with a glass cover and waited up for 1 minute until the suspension was stable. Conidial density was calculated using a microscope with a magnification of $100 \mathrm{x}$ on the haemocytometer $(\mathrm{a}+\mathrm{b}+\mathrm{c}+\mathrm{d}+\mathrm{e})$. The calculation was repeated four times and the density was calculated using formula as follows:

$$
\mathrm{S}=[(\mathrm{t} \times \mathrm{d}) /(\mathrm{b} \times 0.25)] \times 10^{6}
$$

Where: $\mathrm{S}=$ number of conidia per gram of media culture, $\mathrm{t}=$ the number of conidia calculated on the count media ( $a, b, c, d, e), d=$ degree of dilution, $n=$ the number of small squares observed (i.e. $5 \times 16=80$ small squares), and $0.25=$ correction factor (Akagi et al., 2015).

The disease incidence was calculated according to the formula:

$$
\mathrm{IP}=\frac{\mathrm{n}}{\mathrm{N}} \times 100 \%
$$

Note: IP $=$ disease incidence, $\mathrm{n}=$ number of plants attacked, $\mathrm{N}=$ number of plants observed (Noordzij et al., 2010).
AUDPC (area under the disease progress curve) were calculated by the rule that approximate the area under a curve by dividing the area into a number of strips of equal width. Then, the sum of approximate area of each strip by the area of the trapezium formed will give the approximation of area under the curve. The formula used is according to Ling et al. (2017). Plant growth parameters observed included maximum growth potential, germination ability, plant height difference, canopy wet weight, root length, and root wet weight.

\section{Data analysis}

Data were analyzed by analysis of variance (ANOVA) at 5\% level of significance. The significant different results between treatments were further tested using HSD at 5\% significance level.

\section{RESULT AND DISCUSSION}

\section{Conidial density}

Based on Figure 2, the best concentration for growth and development of $T$. harzianum T10 was tapioca flour at $2 \%$ concentration with an increase of $63.28 \%$ compared to PDB. This was presumably because at this concentration the available nutrient content supports the growth of $T$. harzianum $\mathrm{T} 10$ so that the amount of conidia produced is more than other treatments.

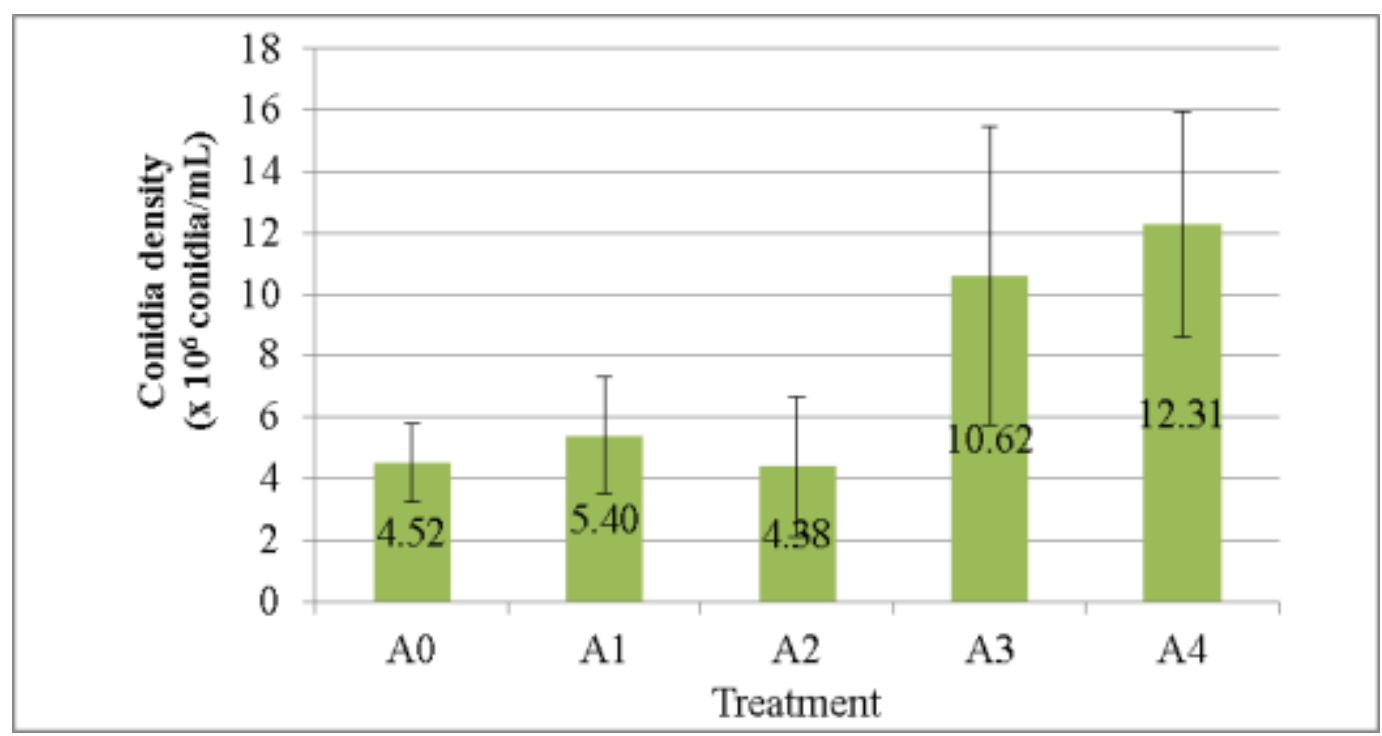

Figure 2. Density of $T$. harzianum $\mathrm{T} 10$ conidia. Note: $\mathrm{A} 0=\mathrm{PDB}, \mathrm{A} 1-\mathrm{A} 4=$ tapioca flour at concentration of $0.5 ; 1 ; 1.5$; and $2 \%$, respectively.

Mishra \& Khan (2015) reported that differences in the number of $T$. viride conidia formed is possible closely related to the nutritional content of substrate. Borin et al. (2015) suggested that the growth of $T$. reesei and Aspergillus niger rely heavily on the availability of carbohydrates that is used as an energy source for growth. 
One of the nutrients contained in tapioca flour (Rose Brand) is carbohydrates by $87.95 \%$ (AOAC, 1999). The carbohydrate content is quite high. Patil et al. (2018) reported that the high carbohydrate content in an ingredient can be a potential source of nutrients and carbon for the growth of the $T$. harzianum fungus. In accordance with a study by Ezeonu et al. (2016), carbohydrates, especially sugar, are mostly used by fungi on a large scale for their metabolic processes.

\section{Incubation period}

The statistical analysis results in Table 1 show that raw secondary metabolites did not significantly influence the incubation period. It means that the raw secondary metabolites produced by $T$. harzianum $\mathrm{T} 10$ have not been able to significantly delay the incubation period of Pythium spp. This is allegedly due to environmental conditions that support the development of Pythium spp. and the fungus could adapt to the new location immediately. In accordance to Sutton et al. (2006), the initial (primary) inoculum in root rot epidemics is chiefly zoospores produced from sporangia formed by germinating oospores, or perhaps by mycelium in plant residues, soil, hydroponic pipes and tubing, and other inoculum sources in the crop environment. This is in line with the report of Muthu (2016) that physical and nutritional factors play an important role in governing reproductive phases of Pythium sp.

Table 1. The effect of treatments on pathosystem component

\begin{tabular}{lccc}
\hline Treatments & Incubation period (dai) & Disease incidence (\%) & AUDPC \\
\hline control & $11.0 \mathrm{a}$ & $55 \mathrm{a}$ & 327.5 \\
T. harzianum T10 + PDB & $17.2 \mathrm{a}$ & $10 \mathrm{~b}$ & 50 \\
T. harzianum T10 + flour 0.5\% & $16.4 \mathrm{a}$ & $20 \mathrm{ab}$ & 155 \\
T. harzianum T10 + flour 1\% & $16.2 \mathrm{a}$ & $20 \mathrm{ab}$ & 90 \\
T. harzianum T10 + flour 1.5\% & $19.0 \mathrm{a}$ & $10 \mathrm{~b}$ & 75 \\
T. harzianum T10 + flour 2\% & $19.0 \mathrm{a}$ & $10 \mathrm{~b}$ & 5 \\
\hline
\end{tabular}

Note: Numbers followed by the same letter in the same column show no significant difference in HSD with an error rate of $5 \%$. dai $=$ days after inoculation. Data on incubation period were transformed to $\sqrt{x}$, data on disease events were transformed to $\arcsin { }_{\mathrm{x}}$.

The average incubation period of the disease in plants applied with the raw secondary metabolites of T. harzianum T10 seems to be delayed by 32.10 $42.11 \%$ compared to controls. In general, the treatments tended to delay the incubation period compared to the control even though statistically the difference was not significant. T. harzianum secretes a wellbalanced cellulolytic complex in tapioca, which efficiently hydrolyzes cellulosic substrates into monomeric glucose. Maximum cellulose activity was obtained with banana flour $(168 \mathrm{U} / \mathrm{ml})$ followed by potato and tapioca flours (Rubeena et al., 2013).

\section{Disease incidence}

The results of the statistical analysis in Table 1 show that the raw secondary metabolites had a significant influence on the incidence of the disease and was in line with the incubation period. PDB and tapioca flour concentration of 1.5 and $2 \%$ were able to reduce the incidence of disease by $81.82 \%$. The treatment of flour concentrations of 0.5 and $1 \%$ can reduce the incidence of the disease by $63.64 \%$.

In general, the raw secondary metabolites could reduce the disease incidence even though the results of treatment using flour concentrations of $0.5 \%$ and $1 \%$ were not significantly different compared to control (Figure 3). The raw secondary metabolites play a role in suppressing the disease incidence. Trichoderma spp. are well known for their ability to produce a wide range of antibiotic substances and for their ability to parasitize the other fungi. Trichoderma spp. produce at least three classes of compounds (peptides, proteins and low-molecular-weight compounds) that generate plant defense responses (Keswani et al., 2019). Secondary metabolites produced in vitro may have antimicrobial activity at high concentration so that the disease incidence will be decreased (Köhl et al., 2019). 


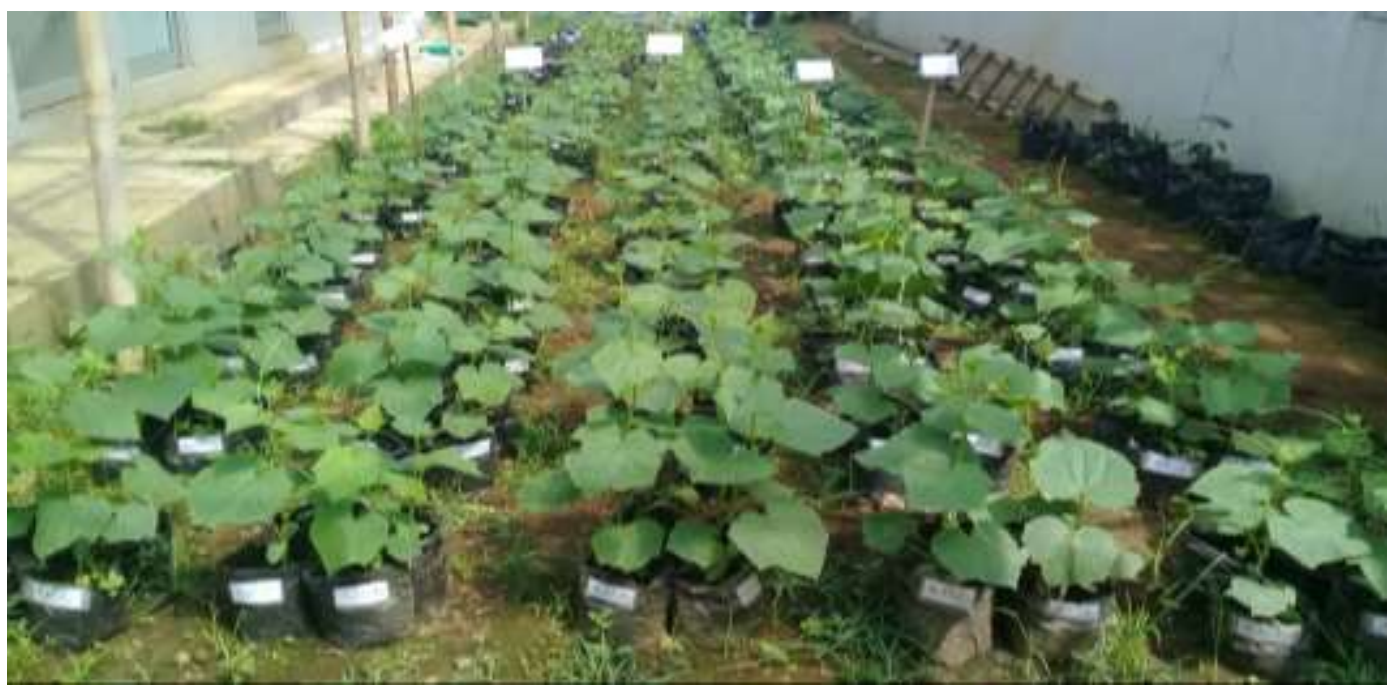

Figure 3. Growth of cucumber after application of the treatments.

\section{AUDPC}

The AUDPCs were calculated numerically using the trapezoidal rule and were plotted for successive assessment dates. Based on Figure 4, the highest AUDPC value occurs in control crop and this is in line with the disease incidence in Table 1 . This condition is due to the absence of secondary metabolites resulted in the greater attack of Pythium spp. than of in the treatment. Plants classified as experiencing disease in this study are exposed to fall and only develop symptoms. According to Gilbert \& Parker (2010), in control plants, the average plants experi- enced the highest disease incidence. The highest disease incidence in control is caused by activity of the pathogens which are more quickly enter and infect plant tissue, and the absence of a mechanism of plant resistance to pathogen infection. This is because of pathogen recognition to crop structure in a several defense responses to inhibit pathogen invasion. One of the first structural barriers that fungal pathogens have to break and enter to their hosts is cell walls. The cell walls are mainly composed of carbohydrates (Rodriguez-Moreno et al. 2017).

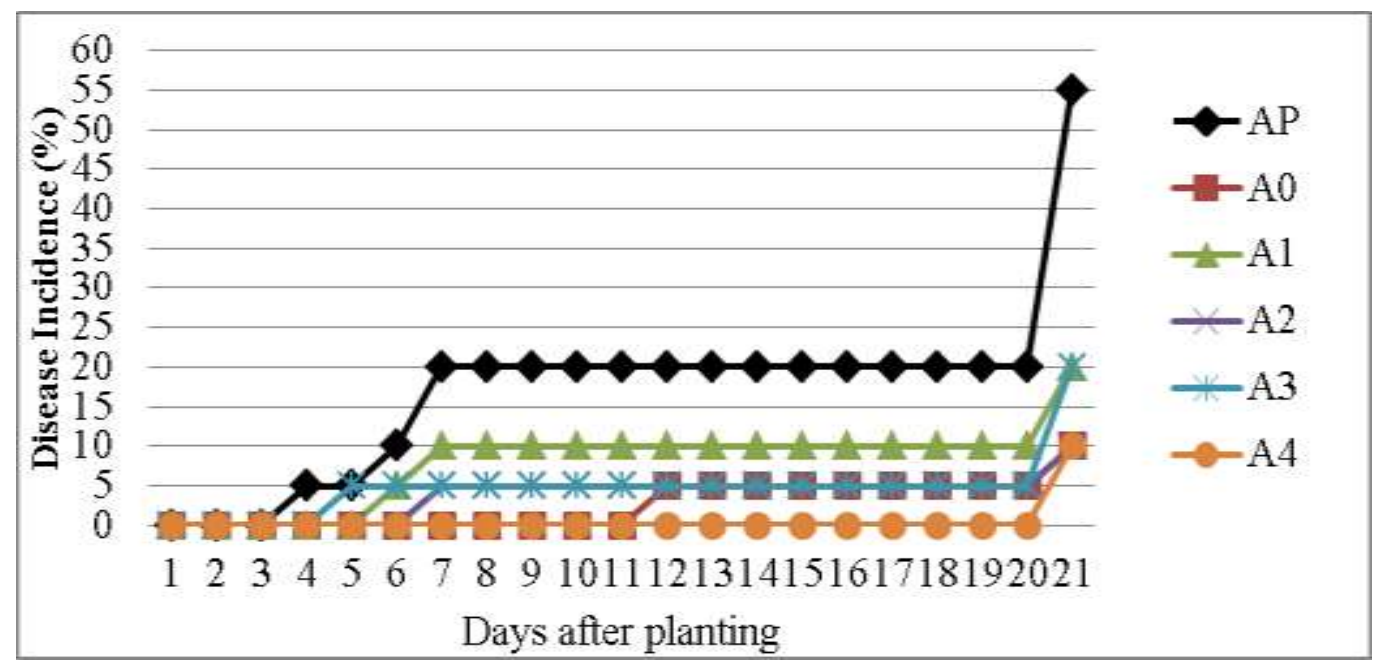

Figure 4. AUDPC value of cucumber seedling damping off. Note: $\mathrm{AP}=$ Control, $\mathrm{A} 0=\mathrm{PDB}, \mathrm{A} 1-\mathrm{A} 4=$ tapioca flour at concentration of $0.5 ; 1 ; 1.5$; and $2 \%$, respectively.

Based on Figure 4, an increase of Pythium spp. infection was seen on the last day of observation. Suffert \& Guibert (2007) stated that the Pythium spp. can also attack after sprouts appear on the ground surface. In older plants, this pathogen can cause injury to the stem. Part of the wound infected with Pythium spp. turns pale and runny causing significant damage to yields.
In general, the raw secondary metabolites of $T$. harzianum can suppress disease progression well. This condition is seen in AUDPC values that because of the raw secondary metabolites, the plants are less likely to develop disease than controls. Mukherjee et al. (2012) and Vinale et al. (2014) stated that T. harzianum produces antibiotics that can reduce the growth of phytopathogenic fungus such as Phytium 
sp. Antibiotic compounds produced by T. harzianum are trichorzins and harzianins (Marik et al., 2019). Both types of compounds are secondary metabolites that are thought to inhibit the growth of pathogenic fungi (Khan et al., 2020).

The lowest AUDPC value was found at $2 \%$ tapioca flour concentration. This is assumed because the $2 \%$ concentration is the highest flour concentration which produces the highest conidia density so that the metabolite compounds produced are thought to be more than the flour concentration lower than the $2 \%$. Hanudin et al. (2013) explained that the lower the AUDPC value, the more effective the treatment is in controlling plant pathogens.

\section{Growth components}

The results of the statistical analysis in Table 2 and Figure 2 show that the raw secondary metabolites did not significantly influence the growth components including maximum growth potential, germination ability, plant height, canopy wet weight, root length, and root wet weight of cucumber. The maximum growth potential of the control group was $95 \%$, while it was more than $95 \%$ in the treatment with raw secondary metabolites. The germination ability of control was $95 \%$, while it was more than $85 \%$ in the treatment with secondary metabolites.

Table 2. The effect of treatment on growth component

\begin{tabular}{ccccccc}
\hline Treatments & MG $(\%)$ & GA $(\%)$ & PH $(\mathrm{cm})$ & RL $(\mathrm{cm})$ & CW $(\mathrm{g})$ & RW $(\mathrm{g})$ \\
\hline Control & $95 \mathrm{a}$ & $95 \mathrm{a}$ & $37.27 \mathrm{a}$ & $29.12 \mathrm{a}$ & $19.81 \mathrm{a}$ & $1.77 \mathrm{a}$ \\
T. harzianum T10 + PDB & $100 \mathrm{a}$ & $95 \mathrm{a}$ & $34.90 \mathrm{a}$ & $36.75 \mathrm{a}$ & $18.57 \mathrm{a}$ & $1.78 \mathrm{a}$ \\
T. harzianum $\mathrm{T} 10+$ flour $0.5 \%$ & $100 \mathrm{a}$ & $90 \mathrm{a}$ & $38.37 \mathrm{a}$ & $27.85 \mathrm{a}$ & $20.40 \mathrm{a}$ & $1.83 \mathrm{a}$ \\
T. harzianum T10 + flour $1 \%$ & $100 \mathrm{a}$ & $100 \mathrm{a}$ & $38.53 \mathrm{a}$ & $31.23 \mathrm{a}$ & $16.14 \mathrm{a}$ & $2.15 \mathrm{a}$ \\
T. harzianum T10 + flour $1.5 \%$ & $95 \mathrm{a}$ & $85 \mathrm{a}$ & $32.00 \mathrm{a}$ & $27.48 \mathrm{a}$ & $18.81 \mathrm{a}$ & $1.65 \mathrm{a}$ \\
T. harzianum T10 + flour $2 \%$ & $95 \mathrm{a}$ & $90 \mathrm{a}$ & $37.45 \mathrm{a}$ & $29.12 \mathrm{a}$ & $19.81 \mathrm{a}$ & $1.71 \mathrm{a}$
\end{tabular}

Note: Numbers followed by the same letters in the same column show no significantly different results in the $5 \%$ HSD after being transformed to $\sqrt{\mathrm{x}}$. MG $=$ maximum growth potential, $\mathrm{GA}=$ germination ability, $\mathrm{PH}=$ plant height, $\mathrm{CW}=$ canopy wet weight, $\mathrm{RL}=$ root length, $\mathrm{RW}=$ root wet weight.

The percentage of germination consisting of maximum growth potential and germination ability in the experiments is quite high. This is presumably because the seeds planted have a good vigor. Good vigor is supported good aeration in control and treatment plants so that the raw secondary metabolites do not have a significant effect. These results are in line with the study by Finch-Savage \& Bassel (2016) that showed that seeds are able to grow normally, even though the natural conditions are not optimum are called seeds that have a good vigor.

Statistical analysis (Table 2) shows that the raw secondary metabolites do not significantly influence the plant height. This is presumably because organic fertilizer given at the beginning of planting is directly responded by the plant as a source of nutrition to stimulate its growth. These results are in line with the research of Shofiyani \& Budi (2014), that explained that the provision of organic fertilizer at the beginning of planting had a direct influence on the availability of nutrients needed by plants during the study so that the role of biological agents had no significant effect.

Cow manure provides essential macro- and micronutrients that are necessary for plant growth. The provision of cow manure can increase the availability of nutrients and absorption of $\mathrm{N}$ elements that are needed in the vegetative growth of plants (Sriyanto et al. 2015). Furthermore, Tola et al. (2007) explained that cow manure contains a number of nutrients and organic matter that can improve the physical, chemical, and biological soil properties. Rifqifauzi (2014) stated that an appropriate level of aeration and nutrient availability is able to support the development of rooting. The development of a good root system determines the vegetative growth of plants which ultimately determines the reproductive phase and yield of plants.

The optimum temperature is thought to support photosynthesis. Cucumber is a thermophilic and frostsusceptible crop, growing best at a temperature above $20^{\circ} \mathrm{C}$ (Singh et al. 2017). The daily temperature observed during the study $\left(28.5^{\circ} \mathrm{C}\right)$ is included in the optimum temperature category.

The novelty of this research is the use of antagonistic fungi in terms of raw secondary metabolites or bioactive compounds and not conidia based. In addition, the discovery of tapioca flour with the right concentration could be used to produce high conidia density and high raw secondary metabolites or bioactive compound.

The benefits of the results are to find other cheaper ingredients in promoting antagonistic fungal growth and the use of antagonistic fungal bioactive compounds to control plant pathogen. 


\section{CONCLUSION}

In conclusion, the most effective tapioca flour concentration for $T$. harzianum growth was $2 \%$, indicated by the highest conidial density $\left(1.23 \times 10^{7}\right.$ conidia $\mathrm{mL}^{-1}$ ) with an increase of $63.28 \%$ compared to PDB. Tapioca flour concentration of $1 \%, 2 \%$ and PDB could reduce the incidence of disease by $81.82 \%$. The lowest AUDPC value was found in flour concentrations of $2 \%$ and the raw secondary metabolite of $T$. harzianum was not been able to significantly delay the disease incubation period. The raw secondary metabolites of $T$. harzianum was not been able to increase the cucumber growth.

\section{REFERENCES}

Akagi, A., Jiang, C., \& Takatsuji, H. (2015). Magnaporthe oryzae inoculation of rice seedlings by spraying with a spore suspension. Bio-protocol, 5(11), e1486.

Aljarah, N. 2017. The activity of Metarhizium sp. to control Pythium aphanidermatum causal agent of cucumber damping off under greenhouse conditions. International Journal of Science and Research (IJSR) 6(8): 1098-1101.

Al-Taweil, H.I., Osman, M.B., Aidil, A.H., \& WanYussof, W.M. (2009). Optimizing of Trichoderma viride cultivation in submerged state fermentation. Am. J. Appl. Sci. 6: 1277-1281.

Bae, S.-J., Park, Y.-H., Bae, H.-J., Jeon, J., \& Bae, H. (2017). Molecular identification, enzyme assay, and metabolic profiling of Trichoderma spp. Journal of Microbiology and Biotechnology 27(6): 1157-1162.

Borin, G.P., Camila Cristina Sanchez, C.C., de Souza, A.P., de Santana, E.S., de Souza, A.T., Leme, A.F.P., Squina, F.M., Buckeridge, M., Goldman, G.H., \& de Castro Oliveira, J.V. (2015). Comparative secretome analysis of Trichoderma reesei and Aspergillus niger during growth on sugarcane biomass. PLoS ONE 10(6): e0129275.

Bouziane, Z., Dehimet, L., \& Chaouch, N.K. (2016). Inhibitory activity of Trichoderma viride against Phytophthora infestans that affects the Spunta potato (Solanum tuberosum L.) variety. African Journal of Microbiology Research 10(29): 11211127.

Chaverri, P., Branco-Rocha, F., Jaklitsch, W., Gazis, R., Degenkolb, T., \& Samuels, G.J. (2015). Systematics of the Trichoderma harzianum species complex and the re-identification of commercial biocontrol strains. Mycologia 107(3): 558-590.

Damiri, N., Mulawarman, \& Mutiara, M. (2014). Effect of temperature and storage on effectiveness of Trichoderma viride as biocontrol agents of
Rigidoporus microporus, pathogen of white root on rubber. AGRIVITA 36 (2): 169-173.

Ezeonu, C.S., Umaru, I.J., Sindama, A., \& Onwurah, I.N.E. (2016). Estimation of total carbohydrate and sugar contents of fungi treated rice husks. FUW Trends in Science \& Technology Journal 1(1): 4549.

Fayadh, M.A. \& Aledani, M.A. (2011). Effect of some microelements and biological control agents in control of tomato seedling damping-off caused by Rhizoctonia solani Kuhn. Basra J. Agric. Sci. 24(1): 53-68.

Finch-Savage, W.E. \& Bassel, G.W. (2016). Seed vigour and crop establishment: extending performance beyond adaptation. Journal of Experimental Botany 67(3): 567-591. DOI:10.1093/jxb/erv490.

Ghazanfar, M.U., Raza, M., Raza, W., \& Qamar, M.I. (2018). Trichoderma as potential biocontrol agent, its exploitation in agriculture: A review. Plant Protection, 02(03): 109-135.

Gilbert, G.S. \& Parker, I.M. (2010). Rapid evolution in a plant-pathogen interaction and the consequences for introduced host species. Evol. Appl. 3(2): 144-156.

Gusnawaty, H.S., Taufik, M., Syair, \& Esmin. (2014). Efektifitas Trichoderma indigenus hasil perbanyakan pada berbagai media dalam mengendalikan penyakit layu Fusarium dan meningkatkan pertumbuhan serta produksi tanaman tomat (Lycopersicum esculentum). Jurnal Agriplus 24 (2): 99-110.

Han, J.S., Cheng, J.H., Yoon, T.M., Song, J., Rajkarnikar, A., Kim, W.G., Yoo, I.D., Yang, Y.Y., \& Suh, J.W. (2012). Biological control agent of common scab disease by antagonistic strain Bacillus sp. sunhua. Journal of Applied Microbiology 99: 213-221.

Hanudin, Nawangsih, A.A., Marwoto, B., \& Tjahyono, B. (2013). Komposisi formula biobakterisida berbahan aktif rizobacteri untuk pengendalian penyakit busuk lunak pada anggrek Phalaenopsis. Jurnal Hortikultura 23 (3): 224254.

Heydari, A. \& Pessarakli, M. (2010). A review on biological control of fungal plant pathogens using microbial antagonists. Journal of Biological Sciences 10(4): 273-290.

Keswani, C., Singh, H.B., Hermosa, R., GarcíaEstrada, C., Caradus, J., He, Y.-W., MezaacheAichour, S., Glare, T.R., Borriss, R., Vinale, F., \& Sansinenea, E. (2019). Antimicrobial secondary metabolites from agriculturally important fungi as next biocontrol agents. Applied Microbiology and Biotechnology 103: 9287-9303. 
Khan, R.A.A., Najeeb, S., Hussain, S., Xie, B., \& Li, Y. (2020). Bioactive secondary metabolites from Trichoderma spp. against phytopathogenic fungi. Microorganisms 8(817).

Köhl, J., Kolnaar, R., \& Ravensberg, W.J. (2019). Mode of action of microbial biological control agents against plant diseases: Relevance beyond efficacy. Front. Plant Sci., 19 July 2019

Lamichhane, J.R., Dürr, C., Schwanck, A.A., Robin, M.-H., Sarthou, J.-P., Cellier, V., Messéan, A., \& Aubertot, J.-N. (2017). Integrated management of damping-off diseases. A review. Agron. Sustain. Dev. 37(10): 1-25.

Ling, A.S.C., Kamil, M.J.A., Chong, K.P., \& Ho, C.M. (2017). Assessing the cocoa genotypes for resistance to black pod using the area under the disease-progress curve (AUDPC). Bulgarian Journal of Agricultural Science 23(6): 972-997.

Marik, T., Tyagi, C., Balázs, D., Urbán, P., Szepesi, A., Bakacsy, L., Endre, G., Rakk, D., Szekeres, A., Andersson, M.A., Salonen, H., Druzhinina, I.S., Vágvölgyi, C., \& Kredics, L. (2019). Structural diversity and bioactivities of peptaibol compounds from the Longibrachiatum clade of the filamentous fungal genus Trichoderma. Front. Microbiol. 10: 1434.

Mishra, P.K. \& Khan, F.N. (2015). Effect of different growth media and physical factors on biomass production of Trichoderma viride. People's Journal of Scientific Research 8(2): 11-16.

Mukherjee. P.K., Horwitz, B.A., \& Kenerley, C.M. (2012). Secondary metabolism in Trichoderma- a genomic perspective. Microbiology 158: 35-45.

Mukherjee, P.K., Horwitz, B.A., Herrera-Estrella, A., Schmoll, M., \& Kenerley, C.M.. (2013). Trichoderma research in the genome era. Annual Review of Phytopathology 51: 105-29.

Munir, S., Jamal, Q., Bano, K., Sherwani, S.K., Bokhari, T.Z., Khan, T.A., Khan, R.A., Jabbar, A., \& Anees, M. (2013). Biocontrol ability of Trichoderma. International Journal of Agriculture and Crop Sciences 6(18): 1246-1252.

Mutawila, C., Vinale, F., Halleen, F., Lorito, M., \& Mostert, L. (2015). Isolation, production and in vitro effects of the major secondary metabolite produced by Trichoderma species used for the control of grapevine trunk diseases. Plant Pathology 65(1): 104-113.

Muthu, K.A. (2016). Occurrence and distribution of indigenous isolates of Pythium species in northern India. Advances in Plants \& Agriculture Research 4(4): 319-327.

Muturi, E.J., Donthu, R.K., Fields, C.J., Moise, I.K., \& Kim, C.-H. (2017). Effect of pesticides on microbial communities in container aquatic habitats. Sci Rep. 7: 44565.
Noordzij, M., Dekker, F.W., Zoccali, C., \& Jager, K.J. (2010). Measures of disease frequency: Prevalence and incidence. Nephron. Clin. Pract. 115:c17-c.

Panahian, G., Rahnama, K., \& Jafari, M. (2012). Mass production of Trichoderma spp. and application. International Research Journal of Applied and Basic Sciences 3 (2): 292-298. .

Patel, R. \& Patel, D. (2014). Screening of Trichoderma and antagonistic analysis of a potential strain of Trichoderma for production of a bioformulation. International Journal of Scientific and Research Publications 4 (10): 1-6.

Patil, A.D. \& Rathore, M.S. (2018). Isolation of pythium species from damping off affected onion rhizospheric soil, using baiting technique. Journal of Pharmacognosy and Phytochemistry 7(4): 1213.

Patil, V.M., Patole, K.R., Paprikar, M.S., \& Rajput, J.C. (2018). Effects of glucose base formulation of Trichoderma viride on seed germination and seedling parameters of tomato (Solanum lycopersicum). Indian Journal of Plant Sciences 7(2): 6-11.

Pathma, J., Rahul, G.R., Kamaraj, K.R., Subashri, R., \& Sakthivel, N. (2011). Secondary metabolite production by bacterial antagonists. Journal of Biological Control 25(3): 165-181. DOI: $10.18311 / \mathrm{jbc} / 2011 / 3716$.

Rahnama, K. (2012). Mass production of Trichoderma spp and application. International Research Journal of Applied and Basic Sciences 3(2): 292-298.

Rashid, M.I., Mujawar, L.H., Shahzad, T., Almeelbi, T., Ismail, I.M.I., \& Oves, M. (2016). Bacteria and fungi can contribute to nutrients bioavailability and aggregate formation in degraded soils. Microbiological Research 183: 26-41.

Rifqifauzi, A. (2014). Pengaruh penyiraman dan dosis pemupukan terhadap pertumbuhan kangkung (Ipomoea reptans) pada komposisi media tanam tanah+pasir. Agrotrop 4 (2): $104-111$.

Rodriguez-Moreno, L., Ebert, M.K., Bolton, M.D., \& Thomma, B.P.H.J. (2017). Tools of the crook infection strategies of fungal plant pathogens. The Plant Journal 93(4): 664-674.

Rostami, F., Alaei, H., Karimi, H.R., \& Abad, A.B. (2015). Controlling the root and stem rot of cucumber, caused by Pythium aphanidermatum, using resistance cultivars and grafting onto the cucurbit rootstocks. Azarian Journal of Agriculture 2(1): 19-24.

Rubeena, M., Neethu, K., Sajith, S., Sreedevi, S., Priji, P., Unni, K.N., Sarath Josh, M.K., Jisha, V.N., Pradeep, S., \& Benjamin, S. (2013). Lignocellulolytic activities of a novel strain of 
Trichoderma harzianum. Advances in Bioscience and Biotechnology 4(2). Article ID:28417,8 pages.

Shofiyani, A. \& Budi, G.P. (2014). Development of Fusarim disease control technology with biological agent in Mas cultivar banana in land infected. AGRITECH 16 (2): 157-173.

Singh, M.C., Singh, J.P., Pandey, S.K., Mahay, D., \& Shrivastva, V. (2017). Factors affecting the performance of greenhouse cucumber cultivationA review. International Journal of Current Microbiology and Applied Sciences 6(10): 23042323.

Soekarno, B.P.W., Surono, \& Susanti. (2014). Formula pelet berbahan aktif Trichoderma sp. dan aplikasinya terhadap penyakit rebah kecambah pada tanaman mentimun. Jurnal Fitopatologi Indonesia 10 (5): 153-159.

Soesanto, L., Kustam, and E. Mugiastuti. 2019. Application of Bio P60 and Bio T10 in combination against phytophthora wilt of papaya. Biosaintifika: Journal of Biology \& Biology Education 11(3): 339-344.

Soesanto, L., Mugiastuti, E., Rahayuniati, R.F., \& Dewi, R.S. (2013). Uji kesesuaian empat isolat Trichoderma spp. dan daya hambat in vitro terhadap beberapa patogen tanaman. Jurnal HPT Tropika 13(2): 117-123.

Sriram, S., Roopa, K.P., \& Savitha, M.J. (2011). Extended shelf-life of liquid fermentation derived talc formulations of Trichoderma harzianum with the addition of glycerol in the production medium. Crop Protection 30: 1334-1339.

Sriyanto, Astuti, D.P., \& Sujalu, A.P. (2015). Pengaruh dosis pupuk kandang sapi terhadap pertumbuhan dan hasil tanaman terung ungu dan terung hijau (Solanum melongena L.). Jurnal AGRIFOR 14 (1): 39-44.
Suffert, F. \& Guibert, M. (2007). The ecology of a Pythium community in relation to the epidemiology of carrot cavity spot. Applied Soil Ecology 35: 488-501.

Sutton, J.C., Sopher, C.R., Owen-Going, T.N., Liu, W., Grodzinski, B., Hal, J.C., \& Benchimol, R.L. (2006). Etiology and epidemiology of Pythium root rot in hydroponic crops: current knowledge and perspectives. Summa Phytopathologica 32(4).

Tola, F. Hamzah, Dahlan, dan Kaharuddin. 2007. Pengaruh penggunaan dosis pupuk bokashi kotoran sapi terhadap pertumbuhan dan produksi tanaman jagung. Jurnal Agrisistem 3 (1): 1-8.

Vinale, F., Sivasithamparam, K., Ghisalberti, E.L., Ruocco, M., Woo, S., \& Lorito, M. (2012). Trichoderma secondary metabolites that affect plant metabolism. Natural Product Communications 7(11): 1545 - 1550.

Vinale, F., Sivasithamparam, K., Ghisalberti, E.L., Woo, S.L., Nigro, M., Marra, R., Lombardi, N., Pascale, A., Ruocco, M., Lanzuise, S., Manganiello, G., \& Lorito, M. (2014). Trichoderma secondary metabolites active on plants and fungal pathogens. The Open Mycology Journal 8(Suppl-1, M5): 127-139.

Wu, Q., Sun, R., Ni, M., Yu, J., Li, Y., Yu, C., Dou, K., Ren, J., \& Chen, J. (2017). Identification of a novel fungus, Trichoderma asperellum GDFS1009, and comprehensive evaluation of its biocontrol efficacy. PLoS One 12(6): e0179957.

Yassin, M.A., El-Samawaty, A.E., Moslem, M.A., \& Sayed, R.M. (2016). Evaluation of potassium and sodium silicates against Fusarium spp. causing damping-off disease of cotton seedling. Fresenius Environmental Bulletin 25(4): 1117-1124. 